\title{
"Ingsun" Misteri Tasawuf Mistik Syekh Siti Jenar
}

\author{
Aris Fauzan \\ Universitas Islam Negeri (UIN) Sunan Kalijaga Yogyakarta. \\ Jl. Laksda Adisucipto, Yogyakarta. \\ Email:aris.fauzan@uin-suka.ac.id
}

\begin{abstract}
The mysticism up to now has been a debatable discourse. The notion and practice to fuse "the self" to "the Creator" understood in so many meanings is an interesting study. No exception the issue also falls on the concept of "Ingsun" or the l-amness solidified by Syekh Siti Jenar. The study is deeply aimed to re-reveal the notion and practice of the prominent figure. According to the writer, the teaching of Ingsun makes serious effort to turn a human consciousness back to authenticity especially in relation to religion. Ingsun opens the awareness that everybody has to actually receive the life always forming a pair among goodnessbadness, life-death and God-servant. Goodness, life and God are the eternal realities of the God. While badness, death and servant are the human realities. Meanwhile the teaching of Ingsun acts as brigde for a gap between human and God. Keywords: Ingsun, The Ultimate Reality, Anthrophocentrism, Syekh Siti Jenar
\end{abstract}

\section{ABSTRAK}

Diskursus mengenai mistisisme saat ini masih menjadi perdebatan. Gagasan dan praktek penggabungan diri atau ke-Aku-an terhadap sang pencipta yang dapat dipahami dari banyak sudut pandang menjadi studi yang menarik. Salah satu issu yang menjadi perdebatan adalah konsep "ingsun" yang dicetuskan oleh Syekh Siti Jenar. Secara mendalam, studi ini bertujuan untuk menegaskan kembali gagasan dan praktek atas figur yang sangat penting. Menurut penulis, pengajaran Ingsun merupakan upaya serius untuk mengembalikan kesadaran manusia terutama dalam hubungannya dengan agama. Konsep "Ingsun" membuka kesadaran bahwa dalam setiap kehidupan selalu ada dua sisi, kebaikan dan keburukan, hidup-mati, Tuhan-hamba. Kebaikan, hidup dan Tuhan adalah bukti akan kekekalan Tuhan. Sedangkan keburukan, mati, dan hamba adalah realitas yang dimiliki manusia. Oleh sebab itu, pengajaran mengenai konsep "ingsun"menjadi jembatan yang memisahkan antara manusia dan Tuhan.

Kata kunci: ingsun, realitas hakiki, antroposentrisme, Syekh Siti Jenar.

\section{PENDAHULUAN}

Pada awal tahun 2004 yang lalu penulis berhasil menyelesaikan tugas akhir S-2 dengan judul "Ajaran Tasawuf Dalam Serat Siti Jenar: Telaah Kritis Atas Serat Siti Jenar Karya Sunan Giri Kedhaton." Dalam tugas akhir berupa tesis itu, penulis berusaha mengungkap ajaran Syekh Siti Jenar sebagaimana yang tertulis di dalam Serat Siti Jenar tersebut. Meskipun tesis tersebut telah disahkan oleh para pembimbing dan sukses dalam ujian munaqasah, tetapi penulis merasa belum mampu mengungkap secara lebih komprehensif ajaran salah satu 
anggota Wali Sanga tersebut. Apalagi Serat Siti Jenar Sunan Giri Kedhaton ${ }^{1}$ tersebut hanya merupakan salah satu sumber dari sekian banyak sumber tertulis yang dinisbahkan sebagai ajaran Syekh Siti Jenar.

Serat Siti Jenar Sunan Giri Kedhaton tersebut merupakan ringkasan dari himpunan Mas Ng. Harjawijaya (1848-1918). Para penghimpun ajaran Siti Jenar lain yang sejaman dengan M. Ng. Harjawijaya adalah Sasrawijaya alias Raden Panjinatarata (18101890), dan Mas Ng. Mangunwijaya (18471917). Raden Panjinatarata menulis ajaran Syekh Siti Jenar dengan judul Serat Siti Jenar ${ }^{2}$. Karya Panjinatarata ini diterbitkan pertama kali oleh penerbit Keluarga Bratakesawa Yogyakarta pada tahun 1958. Sedangkan Mangunwijaya menulis ajaran Syekh Siti Jenar dengan judul Serat Sèh Siti Djenar. ${ }^{3}$ Karya Mangunwijaya ini diterbitkan oleh Pakempalan Widya Pustaka dan dicetak oleh Indonesische Drukkerij di Weltri Preden pada tahun 1917.

Dalam konteks perkembangan agama Islam di tanah Jawa, sebagian ahli menganggap bahwa nama Syekh Siti Jenardengan segala kontroversi yang melekat pada dirinya-sebagai figur yang merepresentasikan salah model keberagamaan (religiusitas) masyarakat Jawa. Beberapa sumber tertulis menyebutkan bahwa Syekh Siti Jenar sejajar dengan sufi martir Abu al-Mughits al-Husain ibn Manshur ibn Muhammad al-Baidhawi (244-301 H) atau al-Hallaj. Sebutan al-Hallajnya orang Jawa ${ }^{4}$ pun melekat padanya.

Sebagaimana al-Hallaj, beberapa literatursesuai dengan penuturan cerita babadmenyebutkan bahwa Syekh Siti Jenar mati di tangan para algojo suruhan penguasanya. Para algojo tersebut melakukan ekskusi atas kematian Syekh Jenar, di antaranya, dengan alasan karena perbedaan pemahaman keagamaan Syekh Siti dengan mainstream pemahaman agama penguasanya.

Syekh Siti Jenar-yang diperkirakan hidup pada masa pemerintahan Sultan Demak Pertama, Raden Patah-sebagai tokoh yang menjadi pusat perhatian dari kalangan masyarakat awam, ulama, maupun penguasanya. Syekh Siti Jenar merupakan salah satu anggota wali sanga yang mengajarkan paham tasawuf wujudiyah (tasawuf yang mengandung ajaran paham wahdat al-wujud) di tanah Jawa. Inti ajarannya tentang ke-Aku-an, I amness, al-Aniyyah, Ingsun, Pribadi, memicu perdebatan di kalangan ulama dan penguasanya. Sebagian sumber menyebutkan karena sikapnya yang gegabah dalam menyebarkan doktrin ke-Aku-an itulah yang mengantarkan dirinya pada pedang para algojo kerajaan.

Masyarakat Indonesia-bagi yang memeluk tradisi Islam-mengenal nama Syekh Siti Jenar sejak abad 16 M. ${ }^{5}$ Mereka mengenal, terutama masyarakat Jawa, Syekh Siti Jenar sama baiknya dengan pengenalan mereka terhadap Wali Songo, ${ }^{6}$ apalagi jika dikaitkan dengan ajarannya tentang manunggaling kawula Gusti ${ }^{7}$ atau wahdat al-wujÔd. ${ }^{8}$ Meskipun banyak faktor yang bisa dikaitkan dengan tokoh Syekh Siti Jenar, tampaknya bagi sebagian ahli cerita kehidupan tasawuffalsafinya lebih menonjol. Sebagian mereka menganggap bahwa ajaran Syekh Siti Jenar hingga sekarang masih terus menjadi rujukan sebagian masyarakat Indonesia, terutama kalangan penganut kebatinan Jawa.

Sesuai dengan hasil penelaahan, penulis berkesimpulan bahwa cerita yang diuraikan dalam babad lebih menekankan sikap politik kerajaan Islam Demak terhadap langkah yang ditempuh Syekh Siti Jenar. Dalam 
konteks kekuasaan-yang merambah pada model pemahaman keagamaan-tokoh Syekh Siti Jenar dituduh sebagai pembangkang dan penganut Islam yang sesat. Cerita pembangkangan dan penganutan Islam yang sesat itu terus disampaikan oleh sebagian masyarakat Jawa secara turun temurun. Sehingga sampai saat ini, masih terdapat kelompok masyarakat yang secara terang-terangan mengkafirkan Syekh Siti Jenar tanpa disertai data yang memadai.

\section{TAFSIR TERHADAP SYEKH SITI JENAR}

Selama kurang lebih satu abad antara abad 19 sampai dengan awal abad 20-atau sekitar 400 tahun setelah kematian tokoh Syekh Siti Jenar-lebih dari satu buku tentang Syekh Siti Jenar diterbitkan. Para penulis menjadikan Syekh Siti Jenar sebagai figur atau lakon utama dalam materi penceritaan. Bahkan mereka menyandarkan ajaran yang terkandung dalam buku-buku tersebut kepada Syekh Siti Jenar. Secara ekplisit para penulis menyebutkan bahwa karya mereka tentang Syekh Siti Jenar merujuk pada Babad Demak dan Serat Walisana dengan memberi judul Serat Siti Jenar atau Suluk Siti Jenar.

Selain itu, munculnya buku-buku yang berusaha mengupas dan memberi tafsiran terhadap Syekh Siti Jenar beserta pemikirannya menginspirasi sebagian kalanagan untuk mendalami kajian terhadap ajaran Syekh Siti Jenar. Buku-buku tersebut adalah; Falsafah Sitidjenar: Ngewrat Pangrembag Paham Wahdatul-Wudjud (Pantheisme) Ing Tanah Djawi, Ingkang Menggok Dados Paham Ngaken Allah Tuwin Ngorakaken Wontenipun Ingkang Nitahaken (Atheisme), karya Bratakesawa (1954), Syekh Siti Jenar, karya Moh. Hari Siti Jenar $( \pm$ 1985), Syekh Siti Jenar: Pergumulan
Islam-Jawa, karya Abdul Munir Mulkhan (2000), Ajaran dan Jalan Kematian Syekh Siti Jenar: Konflik Elite Dan Lahirnya Mas Karebet, karya Abdul Munir Mulkhan (2001), dan Syekh Siti Jenar: Makna "Kematian," karya Achmad Chodjim (2002). Penulis menyimpulkan bahwa dari sekian buku-buku tersebut tidak satu pun yang menggunakan rujukan seluruh karya klasik yang mengupas secara khusus tentang ajaran Siti Jenar.

Bratakesawa, dalam bukunya Falsafah Siti Jenar, ${ }^{9}$ berusaha meluruskan ajaran Syekh Siti Jenar yang menginspirasi gerakan dan paham kaum Sarekat Abangan. Kaum Sarekat Abangan ini merupakan cikal bakal gerakan politik Partai Komunis Indonesia. Bratakesawa menjelaskan bahwa mereka telah memahami secara keliru ajaran Syekh Siti Jenar. Selain itu, Bratakesawa menjelaskan secara singkat sejarah Syekh Siti Jenar serta maksud umum ajarannya yang terdapat dalam Serat Sitidjenar karya Raden Panji Natara. Dalam karyanya itu, Bratakesawa menjadikan Serat Sitidjenar karya Natarata sebagai rujukan utama. Penulis tidak menemukan karya M. Ng. Harjawiaya dan M. Ng. Mangunwijaya sebagai rujukan tambahan. Sehingga dengan menjadikan karya Natarata sebagai rujukan tunggal memungkinkan munculnya pemahaman yang tidak komprehensip tentang pemikiran Syekh Siti Jenar.

Moh. Hari Soewarno merupakan pemerhati dan penulis ajaran Syekh Siti Jenar yang menjadi perhatian penulis. Dalam bukunya yang berjudul Syekh Siti Jenar, ${ }^{10}$ Soewarno memberi informasi yang cukup memadai tentang ajaran Syekh Siti Jenar. Beberapa bagian dari karyanya itu Soewarno menyadur tulisan Bratakeasawa (1954) dan menerjemahkannya ke dalam bahasa Indonesia, terutama dalam bab Mengungkap Nama 
Siti Jenar (11), Isi Ajaran Siti Jenar (15), Ditunggangi Oleh S.I. Merah (20), Karangan r (22), serta Syekh Lemah Abang. Meskipun demikian, berbeda dengan Bartakesawa, Soewarno menyebut sumber lain ajaran Syekh Siti Jenar karya M. Ng. Harjawijaya (lih. hal. 43-70). Seperti terhadap tulisan Bratakesawa, Soewarno pun juga melakukan penerjemahan secara bebas terhadap tulisan M. Ng, Harjawijaya ke dalam bahasa Indonesia. Penulis tidak menemukan secara kritis analisa ilmiah yang terdapat dalam tulisan Soewarno, kecuali pengkuannya bahwa Syekh Siti Jenar sebagai figur yang hadir dalam sejarah nyata dengan berbagai ajaran yang dibawanya.

Abdul Munir Mulkhan dalam bukunya Syekh Siti Jenar: Pergumulan Islam-Jawa, ${ }^{11}$ memberi nuansa lain seputar tokoh Syekh Siti Jenar dan ajarannya dalam konteks Indonesia baru. Dalam bukunya setebal 369 halaman itu, Munir Mulkhan menyajikan Syekh Siti Jenar lebih sistematis serta menggunakan bahasa ilmiah dan populer. Pada bagian awal buku tersebut Munir Mulkhan memaparkan tentang Dimensi Politik Tawauf dan Syekh Siti Jenar. Pada bagian awal ini, Munir Mulkhan mendiskusikan konflik antara institusi agama versus kesadaran beragama, yang populer dengan syari'ah versus tasawuf. Dalam konteks Syekh Siti Jenar, konflik tersebut diwakili oleh kerajaan Islam Demak dengan tokoh Syekh Siti Jenar. Kedua pihak tersebut terlibat konflik karena pijakan memahami dengan menggunakan pendekatan dan tinjauan yang berlainan.

Munir Mulkhan juga memberi penilaian teologis terhadap Syekh Siti Jenar beserta ajarannya dalam tradisi pemikiran Islam. Namun demikian, penilaian Munir Mulkhan ini hanya sepintas lalu saja, tidak menguraikan secara detail model dan tipe teologi dalam ajaran Syekh Siti Jenar. Pada bagian yang lain Munir Mulkhan juga melakukan penyebutan tema-tema pokok yang dibicarakan dalam Serat Sitidjenar. Penyebutan tema-tema pokok itulah, dalam pandangan penulis merupakan sesuatu yang baru, yang tidak disebut secara detail oleh para penulis sebelumnya. Sebagaimana para penulis lain, Munir Mulkhan tidak menggunakan karya penghimpun lain seperti R. Mas Ng Mangunwijaya dan R. Ng. Harjawijaya. Dengan kata lain, Munir Mulkhan menulis tentang ajaran Syekh Siti Jenar dengan menjadikan karya R Panji Natarata sebagai rujukan utama.

Abdul Munir Mulkhan juga menulis tentang ajaran Syekh Siti Jenar. Pada bukunya yang kedua ini, Munir Mulkhan menyoroti ajaran Syekh Siti Jenar terutama tentang kematian, dengan judul, Ajaran dan Jalan Kematian Syekh Siti Jenar: Konflik Elite dan Lahirnya Mas Karebet. ${ }^{12}$ Seperti pada karya sebelumnya, di bagian awal buku ini, Munir Mulkhan memberi uraian tentang humanisasi Islam untuk semua melalui tasawuf. Pada bagian berikutnya, Munir Mulkhan menguraikan pemahamannya atas makna kematian dalam ajaran Syekh Siti Jenar, serta nasib tokoh-tokoh dalam Serat Sitidjenar yang memilih jalan kematian. Pada bab akhir pada bukunya itu, sepertiga lebih dari keseluruhan halaman yang ada, merupakan terjemahan bebas dari Serat Syekh Siti Jenar karya R. Panji Natarata. Pada bagian ini, lagi-lagi Munir Mulkhan tidak menjadikan Serat Siti Jenar lainnya sebagai rujukan untuk memperkaya tulisannya.

Achmad Chodjim adalah pemerhati ajaran Syekh Siti Jenar yang berkesempatan 
menulis pemahamannya atas ajaran Syekh Siti Jenar. Dalam bukunya Syekh Siti Jenar: Makna Kematian, ${ }^{13}$ penulis menyimpulkan bahwa Chodjim hanya menjelaskan kembali apa yang telah ditulis oleh penulis sebelumnya, terutama Abdul Munir Mulkhan. Bisa dikatakan Chodjim adalah penafsir (mufassir) dari pemahaman Munir Mulkhan terhadap ajaran Syekh Siti Jenar. Karena dari hasil pembacaan penulis terhadap karya Chodjim, penulis tidak menjumpai karya lain yang membahas secara khusus ajaran Syekh Siti Jenar kecuali karya Abdul Munir Mulkhan yang berjudul Syekh Siti Jenar: Pergumulan Islam-Jawa dan Ajaran dan Jalan Kematian Syekh Siti Jenar: Konflik Elite Dan Lahirnya Mas Karebet, karya Abdul Munir Mulkhan. Namun demikian, bila dibandingkan dengan tulisan Munir Mulkhan, Chodjim telah menyajikan gagasan ajaran Syekh Siti Jenar lebih detail dengan menggunakan bahasa relatif lebih populer dan istilah-istilah yang lebih filosofis. Berbeda dengan tulisan Munir Mulkhan yang menyertakan analisa teologis, dalam karyanya Chodjim tidak memberi penilaian teologis. Buku setebal 292 itu tidak lebih merupakan refleksi perenungan serta pembacaannya terhadap karya penafsir ajaran Syekh Siti Jenar.

Satu bulan setelah karya Ahmad Chodjim terbit, Abdul Munir Mulkhan menulis kembali sebuah buku yang berjudul Makrifat Burung Surga dan Ilmu Kasampurnan Syekh Siti Jenar. ${ }^{14}$ Berbeda dengan buku-buku tentang ajaran Syekh Siti Jenar yang lain, dalam karyanya kali ini Munir Mulkhan menggunakan rujukan buku utama yang berjudul Serat Bayan Budiman. Buku tersebut berasal dari pemberian seorang rekannya di Jawa Timur. Dalam karyanya ini Munir
Mulkhan mereflekskan perenungannya terhadap buku pemberian sang kawan itu. Sepanjang pembacaan penulis terhadap buku tersebut, penulis tidak menemukan hubungan langsung antara Syekh Siti Jenar dengan Serat Bayan Budiman. Penulis hanya menduga bahwa hubungan antara keduanya-meskipun tidak terdapat hubungan timbal balik secara eksplisitberkaitan dengan ajaran Syekh Siti Jenar dengan kandungan makna dalam Serat Bayan Budiman.

Pada bulan Agustus 2003, Ashad Kusuma Djaya-pimpinan Langgar Padepokan Syekh Siti Jenar Kadipaten Kulon Yogyakartamenulis ajaran Syekh Siti Jenar. Buku tersebut berjudul, Pewaris Ajaran Syekh Siti Jenar: Membuka Pintu Makrifat. ${ }^{15}$ Dalam melengkapi tulisannya tersebut Kusuma Djaya mengambil rujukan utama dari Babad Julasutra, ${ }^{16}$ Suluk Malang Sumirang, ${ }^{17}$ Babad Jaka Tingkir, ${ }^{18}$ dan Serat Siti Jenar. ${ }^{19}$ Kedua buku yang pertama tersebut merupakan rujukan baru yang penulis jumpai dari serangkaian buku tentang Syekh Siti Jenar yang sudah ada.

Dalam karya Kusuma Djaya tersebut penulis tidak menemukan sesuatu yang baru dari para penulis yang lainnya, kecuali rujukan yang baru. Penulis memahami Kusuma Djaya berusaha mempertemukan ajaran Syekh Siti Jenar dengan pengetahuan modern. Tetapi tidak menyinggung sedikitpun tentang konsep Ingsun yang menjadi salah satu ajaran Syekh Siti Jenar.

Pada tahun 2004, Abdul Munir Mulkhan kembali menulis buku yang menghubungkan dengan Sekh Siti Jenar, dengan judul Makrifat Siti Jenar: Teologi Pinggiran Kehidupan Wong Cilik. ${ }^{20}$ Penulis memahami bahwa buku setebal 389 halaman tersebut tidak lain 
merupakan perluasan penjelasan Munir Mulkhan atas perenungannya terhadap ajaran Syekh Siti Jenar yang ditulis oleh Panjinatarata. Selain itu, Munir Mulkhan berupaya membawa ajaran dan kehadiran Siti Jenar dalam konteks yang lebih komprehensif; politik, ekonomi, sosial budaya, sikap keberagamaan pribadi maupun kelompok, dan wilayah teologi. Dalam kaitannya dengan religiusitas Munir Mulkhan menegaskan bahwa kehadiran cara beragama Syekh Siti Jenar merupakan representasi dari kaum pinggiran (wong cilik, rakyat) berhadapan cara beragama kaum bangsawan dan para penguasa pada zamannya. Secara ekplisit Munir Mulkhan menyimpulkan bahwa kehadiran Syekh Siti Jenar beserta ajarannya merupakan realitas sejati cara beragama yang sesungguhnya. Suatu cara beragama yang manusiawi, jujur (tidak berpura-pura), dan membela kaum tertindas.

Baik Bratakesawa, Moh. Hari Soewarno, Abdul Munir Mulkhan, Ashad Kusuma Djaya, maupun Achmad Chodjim mereka menjadikan Serat Siti Jenar karya Panjinatarata sebagai rujukan utama. Karya Harjawijaya dan Mangunwijaya tidak mereka jadikan sebagai rujukan. Penulis menyimpulkan bahwa tulisan Siti Jenar karya Harjawijaya dan Mangunwijaya-meskipun lahir beberapa tahun setelah Panjinataradisertakan sebagai rujukan dalam mengungkap ajaran Syekh Siti Jenar. Sehingga pemahaman tentang ajaran Syekh Siti Jenar semakin lebih komprehensif. Bermula dari ketidaklengkapan rujukan tersebut penulis menyimpulkan bahwa tulisan-tulisan tentang ajaran Syekh Siti Jenar tersebut tidaklah lengkap.

Selain itu, dari beberapa tulisan yang penulis telaah, masing-masing buku tersebut tidak satu pun yang secara tegas menyebutkan ajaran inti Siti Jenar yakni tentang Ingsun, Prabu Satmata, ${ }^{21}$ Sang Hyang Manon, I-ness, atau ke-Aku-an. Ajaran tentang ingsun inilah yang menurut penulis merupakan maniverstasi puncak dari pengalaman beragama dan berspiritual. Ke-Aku-annya yang menjadi pertimbangan para wali untuk menjatuhi hukuman mati pada Syek Siti Jenar. Ke-Aku-annya ini menjadi bukti nyata bahwa Syekh Siti Jenar telah membocorkan rahasia tertinggi. ${ }^{22}$

Berpijak dari adanya beberapa rujukan penting tentang ajaran Syekh Siti Jenar serta konsep ke-Aku-an yang diucapkan oleh Syekh Siti Jenar itulah, membuka sejumlah pertanyaan, seperti; Apakah ke-Aku-an itu sama dengan ego? Apakah ketika mengucapkan Ingsun sebagai Prabu Satmata itu dalam keadaan hulul atau ittihad? Ataukah ungkapan ke-Aku-an itu muncul sebagai refleksi spiritual-filosofis (wahdah al-syuhud) yang terjadi dalam diri Syekh Siti Jenar? Ataukah ucapan Syekh Siti Jenar itu hanyalah ucapan para kaum yang gila karena Allah (majnunullah) yang tidak perlu harus dikenai sanksi? Terlepas dari pertanyaanpertanyaan tersebut di atas, setidaknya semakin membuka munculnya pemahaman baru bahwa terdapat gagasan yang lebih penting dari sekedar sikap Siti Jenar berlawanan dengan penguasa.

\section{KE-AKU-AN SEBELUM SYEKH SITI JENAR}

Sebenarnya, jauh sebelum kehadiran Syekh Siti Jenar fenomena munculnya konsep ke-Aku-an sudah ada sejak abad $3 \mathrm{H}$, yang ditampilkan oleh Abu Yazid al-Busthami (w. $261 \mathrm{H}$ ). Dalam suatu kesempatan secara 
nyata Abu Yazid mengaku dirinya Allah. "Anaallah, Laa Ilaaha Illa Anaa Fa'buduuni: Aku Allah, Tiada Tuhan kecuali Aku, maka sembahlah Aku,"23 "Suatu ketika Dia (Yang Maha Benar) mengangkatku dan menundukkan aku di antara tangan-Nya. Maka ujar-Nya padaku: Abu Yazid! Makhlukmakhluk-Ku senang melihatmu. Jawabku: Hiasilah aku dengan keesaanMu, pakaikanlah aku dengan keakuan-Mu, dan angkatlah aku ke ketunggalan-Mu. Sehingga apabila makhluk-makhluk-Mu melihatku, mereka akan berkata: Kami telah melihatMu. Dan Engkau pun menjadi aku yang di sana, dan aku tidak berada di sana." 24 Kehadiran Abu Yazid dengan ungkapannya itu pada zamannya bukan merupakan sesuatu yang ganjil.

Para pemerhati tasawuf baik yang hidup sezaman atau pun sesudah Abu Yazid memberi apresiasi yang positif terhadap ungkapannya. Abu al-Wafa merujuk para penulis seperti al-Sulami dalam karyanya Thabaqat al-Shufiyyah, al-Thusi dalam karyanya al-Luma, dan al-Qusyairi dalam karyanya alRisalah al-Qusyairiyah, menyimpulkan bahwa menurut para penulis buku tersebut apa yang diungkapkan Abu Yazid sejalan dengan alQur'an dan al-Sunnah. ${ }^{25}$ Para sufi menyebut pengalaman Abu Yazid itu, dengan sebutan fana atau trance. Al-Junaid mengatakan bahwa trance seorang sufi tidak mengucapkan tentang dirinya sendiri, tetapi tentang apa yang disaksikannya, yaitu Allah. ${ }^{26}$ Menurut W.T. Stace pengalaman al-Busthami merupakan kesadaran untuk bersatu (unitary consciousness). ${ }^{27}$ Dengan kata lain, bahwa apa yang diucapkan Abu Yazid al-Busthami merupakan hal yang wajar dalam tradisi keagamaan, khususnya Islam.

Selain Abu Yazid, tokoh yang menggunakan konsep ke-Aku-an adalah Abu al-Mughisy al-Husain ibn Manshur ibn Muhammad al-Baidhawi (w. 244-301 H). Tidak seperti Abu Yazid, al-Hallaj harus mengakhiri hidupnya di tiang salib. Penguasa pada zamannya menuduhnya sebagai orang sesat dari keislaman, karena ungkapan keAku-an itu. Di antara pernyataan adalah, "Duh, penganugerah bagi pemegang karunia. Terhadap diri-Mu dan diri-Ku begitu aku terpana. Kau buat begitu dekat diriku dengan-Mu, sehingga. Kau adalah aku, begitu kiraku. Kini dalam wujud diriku menjadi sirna. Dengan-Mu aku kau buat menjadi fana."

Namun demikain, para ahli tasawuf memberi penilaian yang beragam terhadap apa yang dialami al-Hallaj. Mayoritas menilai bahwa al-Hallaj telah menyimpang dari ajaran Islam. Akhir kematiannya yang tragis dengan cara disalibkan dan dibakar di tengah lapangan seakan menjadi bukti bahwa alHallaj telah menganut ajaran yang sesat. ${ }^{28} \mathrm{Ke}$ Aku-an al-Hallaj sebagai Sang Kebenaran tidak diterima secara wajar seperti ke-Aku-an yang diucapkan oleh Abu Yazid al-Busthami. Akibat ke-Aku-annya itu dia harus menemui ajalnya dengan cara yang sangat menyedihkan.

Komentar positif, yang berisi dukungan dan pembelaan terhadap apa yang dilakukan al-Hallaj, datang dari berbagai tokoh sufi besar dalam Islam. Mereka ${ }^{29}$ adalah Ibn Suraih, ${ }^{30}$ seorang ulama fiqh dari madzhab Maliki; Imam Ghazali, Jalal al-Din al-Rumi, ${ }^{31}$ Farid al-Din al-'Aththar, ${ }^{32}$ Abdulqadir alJailani, ${ }^{33}$ dan al-Damiri. ${ }^{34}$ Tokoh-tokoh tersebut tidak memberi penolakan terhadap apa yang dialami al-Hallaj. Bahkan sebagian dari mereka menjadi rujukan umat Islam di seluruh dunia. 
Selain Abu Yazid al-Busthami dan al-Hallaj pada abad 15 terdapat pula tokoh yang mengaku sebagai Kebenaran. Dia adalah Ismail (w. 1524). Sesuai dengan anggapan para sejarawan tentang Ismail yang beranggapan bahwa dirinya merupakana inkarnasi Tuhan..$^{35}$ Mereka menyebut kekuasaan Ismail sebagai pemerintahan Tuhan. Ismail juga menulis puisi yang sebagian berisi dirinya yang merupakan penjelmaan dari Tuhan. ${ }^{36}$ Berikut pernyataan Ismail yang menyatakan dirinya sebagai Kebenaran;

The secret of 'I am the Truth (haqq)' is hidden in this heart of mine

For I am the absolute Truth and what I say is the Truth. ${ }^{37}$

Artinya:

Rahasia akan Aku Sang Kebenaran

tersembunyi dalam hati milikku

Karena Aku Kebenaran Mutlak, maka apa yang aku ucapkan adalah Kebenaran

Istilah al-Haqq daam ucapan Ismail tersebut secara berarti Kebenaran Lisan melemahkan penguasaan atas pendewaan-diri (self-deification). Tetapi pernyataan tersebut dibantah oleh pernyataan lain dari Ismail seperti berikut:

I am the eye of God I am the eye of God the eye of God

Come now and see the Truth O blind man who have lost your way

I am that absolute doer of whom they tell I am the commander of the sun and moon My existence is the House of God know for sure

Prostration to me is incumbent upon you in the evening and at daybreak ${ }^{38}$
Artinya:

Aku adalah mata Tuhan Aku adalah mata Tuhan mata Tuhan

Kini datang dan lihatlah Sang Kebenaran, wahai orang buta yang tersesat

Aku adalah pelaku Mutlak itu yang mereka ceritakan

Aku adalah komandan matahari dan bulan Wujudku adalah Rumah Allah mengetahui karena yakin

Sujud padaku adalah berkewajiban padamu pada saat sore dan fajar

Tidak jauh berbeda dengan figur Syekh Siti Jenar. Tokoh yang dalam cerita babad dianggap sebagai pembangkang para Wali Sanga ini pun mengalami hal yang sama dengan al-Hallaj. Ia harus mati dihadapan para Wali Sanga sebagai wujud pengakhiran atas ke-Aku-annya yang dianggap menyimpang dari ajaran Islam. Tokoh Siti Jenar tidak semulus para sufi yang lainnya, seperti Abu Yazid al-Busthami dan Ismaili. Bahkan sebagian masyarakat Islam Indonesia-yang berorientasi pada kebenaran fiqhiyah-menganggap Siti Jenar sebagai tokoh sesat yang menyimpang dari ajaran Islam. Padahal sebagian mereka menjadi pengikut aliran tarikat Qadiryah.

\section{WACANA KE-AKU-AN}

Wacana ke-Aku-an sebenarnya merupakan gagasan abadi yang akan muncul sepanjang zaman. Syekh Siti Jenar-dalam konteks Islam Indonesia merupakan varian lainmeruapakn salah dari mata rantai keabadian gagasan tersebut. Dia telah memperkenalkan ke-Aku-annya sebagai bagian dari perjalanan hidup sejatinya. Sebelum Siti Jenar, para nabi, rasul, wali, santo, dan orang-orang suci lainnya telah memperkenalkannya. Hanya 
saja tanggapan dari masyarakat yang hidup sezaman dengan mereka memberi respon yang beragama. Mereka adalah orang-orang yang mencapai pemahaman yang secara sempurna akan ke-Aku-annya. Sayangnya, untuk kasus Siti Jenar pengantar akan keAku-annya itu justru disambut dengan tuduhan atas dirinya sebagai orang yang telah keluar dari agama bahkan tidak beragama.

Ke-Aku-an atau Ingsun atau Ananiyyah, atau the I-amness merupakan sesuatu yang inhern dalam kehidupan setiap manusia. Karena Ingsun merupakan sumber dari kisah penciptaan. ${ }^{39}$ Hanya saja tidak setiap manusia mau dan atau mampu menerimanya sebagai bagian dari dirinya. Siti Jenar-dan siapa pun yang memahami Ingsun-sudah secara tidak langsung telah menghayati dua wilayah sekaligus, yaitu; Ingsun dalam konteks raga/ fisik/ badan dan Ingsun dalam konteks the Ultimate Reality. Pada konteks Ingsun raga berorientasi pada pijakan tubuh fisik yang meliputi bukan hanya pada badan melainkan juga jiwa dan nyawa. Pada konteks ini Siti Jenar melalui muridnya-Ki Kebokenongomenguraikan bahwa agama seharusnya mengarahkan setiap para pemeluknya menjadi orang yang hidup menyatu dengan alam dan merdeka. Yaitu hidup yang berupaya menerima realitas antara kebaikan (becik, goodness) dengan keburukan (ala, badness), kehidupan (urip, life) dengan kematian (pralaya, death), dan Tuhan (Gusti, God) dengan hamba (kawula, slave). Berikut ajaran Siti Jenar,

Wong neng nusapada iki,

Mung mengku kalih prakara,

Ala becik loro kuwe,

Urip jodhone pralaya,

Gusti lawan kawula,

Nanging Kyageng Pengging tambuh,
Wong mati tan ngrasa laya. ${ }^{40}$

Artinya:

Manusia yang berada di alam semesta ini, Hanya menhadapi dua persoalan,

Baik buruk berpasangan dengan kamu,

HIdup berpasangan dengan mati,

Tuhan bersama hamba,

Tetapi Kyageng Pengging tidak memahaminya,

Orang yang mati tidak merasakan mati

Dalam kaitannya Ingsun ragawi akan senantiasa berhadapan dengan keburukan, kematian, dan kehambaan. Ketiga hal tersebut menjadi realitas wajib yang melekat pada setiap manusia, yang seharusnya disadari setiap manusia. Pada tataran ini Ingsun ragawi adalah ingsun yang relative. Ingsun ragawi adalah yang senantiasa berubah wujud, bentuk, dan tempat. Pada Ingsun inilah inilah mungkin yang oleh Paul F Knitter disebut dengan anthropocentrism. ${ }^{41}$ Pada Ingsun ini pula manusia sebagai imago dei, citra ilahi yang nyata. Bahkan berpijak pada Ingsun ini pulalah kesadaran akan adanya Pencipta (Khaliq, Creator), ciptaan (makhluq, creatures), dan etika (akhlaq, ethic). Hubungan antara Tuhan dan Hamba itulah yang secara sosial dan rohani melahirkan hokum-hukum yang mendamaikan. Hokum-hukum yang tidak diatur dan ditentukan oleh penguasa yang mengatasnamakan agama, melainkan hokum-hukum yang berpijak pada setiap kesadaran diri individu yang tercerahkan yang senantiasa mendamaikan diri, orang lain, dan alam sekitar.

Sementara itu Ingsun dalam konteks Ilahi adalah Ingsun yang Abadi. Ingsun dalam hal ini adalah Ingsun yang senantisa berkaiatan dengan the Ultimate Reality, Tuhan, Gusti, atau Sang Kebenaran.Ingsun Ilahi adalah Ingsun sebagaimana dikatakan dan disaksikan 
oleh Abu Yazid al-Busthami, al-Hallaj, dan Ismaili. Ingsun dalam hal ini adalah Ingsun yang hanya diperintah secara langsung oleh Tuhan. Proses pencapaian kesadaran akan Ingsun Ilahi pada diri manusia biasanya melalui perjalanan spiritual yang disebut dengan ittihad ${ }^{42}$ dan hulul. ${ }^{43}$ Pada saat seseorang merasakan dirinya sebagai Ingsun Ilahi itu biasa disebut dengan wahdat al-syuhud atau wahdat al-wujud. Biasanya pula orang yang mengalami demikian sering mengatakan sesuatu (yang disebut syathohat) yang terkadang berlawanan dengan pandangan masyarakat umum. Meskipun demikian, sebagian kalangan muslim memahami bahwa orang yang mengalami demikian tidak bisa dihukum sesuai dengan hokum agama.

Implikasi dari Ingsun Ilahi ini adalah adanya pemahaman bahwa Ingsun Ilahi yang bersemayam dalam diri manusia adalah Ingsun Sang Abadi, Ingsun Yang Mutlak. Ingsun inilah yang merupakan the Ultimate Reality yang harus disembah oleh setiap hamba. Ingsun Sang Abadi ini juga bersemayam di dalam diri setiap manusia, hanya saja tidak semua orang menyadarinya. Selain itu, tidak semua orang meneladani Tuhan secara baik. Oleh karena itu, meskipun setiap manusia adalah Ingsun Ilahi tetapi tidak setiap orang pula mengakui dirinya sebagai Tuhan. Untuk bisa memahami bahwa dirinya adalah Tuhan Yang Nyata, manusia harus melewati latihan spiritual serta perjalanan rohani yang tidak gampang. Manusia yang mengaku dirinya sebagai Ingsun Ilahi dia harus meneladani sifat-sifat Tuhan dan bersifat sebagaimana sifat 20 yang ada pada Tuhan.

Orang yang telah mampu meneladani perbuatan Tuhan, maka orientasi hidupnya akan senantiasa pada bagaimana menjunjung tinggi kebaikan, Tuhan, dan kehidupan, mungkin ketiga komponen itu oleh Paul F Knitter disebut dengan biocentrism. ${ }^{44}$ Suatu paham yang berorientasi pada keabadian yaitu kebaikan abadi, Tuhan, dan kehidupan itu sendiri. Suatu keabadian yang tidak hanya berorientasi atas nama Tuhan, melainkan juga atas nama seluruh makhluk Tuhan yang diberi kesempatan hidup oleh Tuhan. Karena dalam diri seluruh makhluk itu Tuhan menampakkan Diri-Nya. Meskipun demikian, tidak lantas setiap makhluk Tuhan adalah Tuhan, karena Tuhan adalah berbeda dengan seluruh makhluk-Nya.

\section{KESIMPULAN}

Wacana ke-Aku-an (Ingsun) sebenarnya bukan sesuatu yang baru dalam dunia Islam. Sayangnya sebagian umat Islam-terutama di Indonesia-memahami secara tidak komprehensif konsep Ingsun tersebut. Apalagi jika tulisan-tulisan yang berkaitan dengan ajaran Ingsun itu lebih menitikberatkan pada uraian politik dan sikap keberagamaan yang berbeda dengan penguasa suatu zaman. Sehingga hakekat Ingsun itu menjadi kabur. Selain Syekh Siti Jenar, tokoh-tokoh Islam seperti Abu Yazid alBusthami, al-Hallaj, dan Ismaili telah mengawali ajaran Ingsun tersebut. Hanya saja perhatian masyarakat tidak meyeluruh, sehingga Ingsun itu kehilangan makna aslinya.

Sebenarnya, ajaran Ingsun berupaya mengembalikan kesadaran manusia pada kesejatiannya terutama berakitan dengan agama. Ingsun membuka kesadaran bahwa setiap manusia harus menerima kenyataan hidup ini yang selalu berpasangan baik-buruk, kehidupan-kematian, dan Tuhan-hamba. 
Kebaikan, kehidupan, dan Tuhan adalah realitas Abadi Tuhan. Sedangkan, keburukan, kematian, dan hamba adalah realitas manusia. Ajaran Ingsun menjembatani kesenjangan antara manusia dan Tuhan itu sendiri.

\section{CATATAN AKHIR}

1 Secara eksplisit penerbit Serat ini menuturkan bahwa Boekoe Siti Djenar ini merupakan ringkasan dari Serat Walisana karya Harjawijaya. Penerbit Tan Khoen Swie menyebutkan bahwa apa yang ditulis oleh Panjinatarata maupun Mangunwijaya masih menyimpang dari ajaran Syekh Siti Jenar yang sesungguhnya. Selanjutnya penerbit tersebut menyebutkan bahwa terbitannya merupakan ajaran cerita Syekh Siti Jenar yang bersumber dari Sunan Giri Gajah atau Sunan Giri Kedhaton. Selanjutnya lih., Tan Khoen Swie, Boekoe Siti Djenar Ingkang Toelen, Kediri, 1931

2 Karya Panji Natarata tersebut secara khusus menceritakan kembali tentang diskusi yang dilakukan oleh Syekh Siti Jenar dengan Ki Kebo Kenongo. Kebo Kenongo nama lain dari Ki Handayaningrat. Dia adalah keturunan langsung dari Raja Barawijaya V, raja dari Kerajaan Majapahit yang terakhir.

3 Karya Manugunwijaya ini pada mulanya ditulis dalam huruf dan bahasa Jawa. Selanjutnya ditulis kembali dan dialihaksarakan ke dalam huruf latin oleh Museum Radyaspustaka Surakarta pada bulan Januari 1970. Pada tahun 1981 Serat Seh Siti Djenar ini diterjemahkan ke dalam bahasa Indonesia oleh Sutarti. Serta ini diterbitkan oleh Departemen Pendidikan dan Kebudayaan, Proyek Penerbitan Buku Sastra Indonesia Dan Daerah. Penulis mempunyai tiga macam tulisan dengan judul yang sama tetapi dari percetakan yang berlainan.

4 Mohammad Sobary, Pengantar: Kewibawaan 'Subversif' Syekh Siti Jenar, dalam Abdul Munir Mulkhan, Syekh Siti Jenar: Pergumulan Islam-Jawa, (Yogyakarta: Bentang Budaya, 2000), cet., ke-5, h. vi.

5 Abdul Munir Mulkhan, Syekh Siti Jenar: Pergumulan Islam-Jawa, (Yogyakarta: Bentang Budaya, 2000), cet., ke-5, h. 2.

6 Abdul Munir Mulkhan, et. al., Bisnis Kaum Sufi: Studi Tarekat Dalam Masyarakat Industri, (Yogyakarta: Pustaka Pelajar, 1998), cet., ke-1, h. 24. Lih., juga Abdul Munir Mulkhan Syekh Siti Jenar: Pergumulan Islam-Jawa, h. 1-2.

7 Abdul Munir Mulkhan, Syekh Siti Jenar: Pergumulan Islam-Jawa, h. 2.

8 Konsep wahdat al-wujud secara ideologis dicetuskan oleh Muhyiddin Ibn 'Arabi (w. 638 H/ 1240M), selanjutnya sebagai istilah filsafat dan tasawuf dipopulerkan oleh Sadr al-Din al-Qunawi (w. $673 \mathrm{H}$ / $1274 M)$. Konsep wahdat al-wujud itu sejak awal Islam menjadi perdebatan yang belum berakhir di kalangan umat Islam.

9 Penulis menemukan buku tersebut dari perpustakaan Kolese Ignatius di Yogyakarta dengan nomor pendaftaran KI BR 78 D 5. Buku yang ditulis pada tahun 1954 tersebut diterbitkan oleh Penerbit Yayasan Penerbitan Djojobojo Surabaya, merupakan cetakan yang ke-6.

10 Secara eksplisit penulis tidak menemukan tanggal dan tahun diterbitkannya buku tersebut. Namun demikian berdasarkan pada buku-buku yang dijadikan sebagai rujukan yang paling tua berangka tahun 1985, besar kemungkinan buku tersebut ditulis oleh Soewarno pada tahun sekitar tahun 1985-1986. Buku tersebut diterbitkan oleh penerbit PT Antar Surya Jaya, tetapi tidak menyebutkan pula tempat dan kota mana penerbitan tesebut berada.

11 Buku-yang merupakan best seller antara tahun 19992000-tersebut diterbitkan oleh Bentang Budaya Yogyakarta. Buku-yang pertama kali dicetak pada tahun 1999-yang berada ditangan penulis merupakan cetakan ke-5 pada tahun 2000.

12 Buku-yang dicetak pertama kali pada bukan Juni 2001-tersebut diterbitkan oleh penerbit Kreasi Wacana Yogyakarta. Penulis mengoleksi buku tersebut yang terbit pada bulan Juli 2001 pada penerbitan yang kedua. http://mail.yahoo.com/config/login?/ym/ Compose?DMid=4846_6414200_5603_488_299_0_5376_1_o\&YY=417098y 5 beta =yes $8 y 5$ beta $=$ yes $\theta$ inc $=258-$ order=down\&sort=date\&pos=0\&view=a\&head =b\&box=Draft - _ftnref14

13 Buku-yang terbit pertama kali pada bulan Juni 2002-ini diterbitkan oleh penerbit Serambi Ilmu Semesta Jakarta. Buku yang ada ditangan penulis merupakan terbitan yang ke-3 pada bulan November tahun 2002.

14 Buku ini diterbitkan pada Desember 2002 oleh penerbit Kreasi Wacana Yogyakarta. Buku yang tebalnya 547 halaman itu separo bagian pertama merupakan tafsir kontekstual ajaran Syekh Siti Jenar, sedangkan bagian kedua merupakan terjemahan bebas Serat Bayan Budiman.

15 Buku setebal 256 halaman itu diterbitkan oleh Kreasi Wacana Yogyakarta.

16 Menurut Kusuma Djaya Babad Jalasutra ini diterbitkan oleh penerbit Sumodidjojo Mahadewa. Babad ini menceritakan perjalanan Pangeran Panggung sejak masa kerajaan Demak sampai berdirinya kerajaan Mataram yang akhirnya dipimpin Sultan Agung Hanyakrakusuma

17 Kusuma Djaya mengungkapkan bahwa Suluk Malang Sumirang merupakan kutipan dari Serat Walisana. 
Penulis mempunyai naskah lengkap Serat Walisana yang diterbitkan oleh penerbit Tan Khoen Swie pada tahun 1925. Sementara itu versi latin yang ditulis ulang oleh R Tanojo penulis telah mendaptkan salinannya dari perpustakaan Kolese Ignatius dengan nomer pendaftaran KI 78 C 440.

18 Di tangan penulis Babad Jaka Tingkir ini telah diterjemahkan ke dalam bahasa Indonesia oleh Moelyono Sastronaryatmo dan diterbitkan dalam versi terjemahan oleh Departemen pendidikan dan Kebudayaan Jakarta tahun 1981.

19 Serat ini merupakan rujukan utama bagi sebagian besar para penulis yang mengungkap tentang ajaran Syekh Siti Jenar.

20 Buku ini terbit pertama kali pada September 2004, merupakan cetakan pertama yang diterbitkan oleh Grafindo Khazanah Ilmu di Jakarta.

21 Muhsin Labib dalam karyanya, Mengurai Tasawuf Irfan dan Kebatinan, (Jakarta: Lentera, 2004), h. 218, menjelaskan bahwa Prabu Satmata merupakan gelar Sunan Giri Kedaton. Penjelasan ini berbeda dengan uraian yang terdapat dalam cerita Babab maupun dalam Serat Siti Jenar yang lainnya. Baik cerita babab maupun Serat Siti Jenar menjelaskan bahwa yang bergelar Prabu Satmoto adalah Syekh Siti Jenar.

22 D.A. Rinkes, De Helligen van Java II: Sjeh S iti Djenar voor de Inquititie, terj. M. Soenjata Kartadarmadja, (Jakarta: Departemen Pendidikan dan Kebudayaan, 1986), h. 11. Lihat pula dalam P.J. Zoetmulder, Manunggaling Kawula Gusti: Pantheisme dan Monisme Sastra Suluk Jawa, terj. Dick Hartoko, (Jakarta: Gramedia Pustaka Utama, 1991), cet., ke-2, h. 352-367.

23 Abu al-Wafa al-Ghanimi al-Taftazani, Madkhal ila alTashawwuf al-Islam, terj. Ahmad Rofi' Utsmani, (Bandung: Pustaka, 1997), cet., ke-2, 116. Selain itu Abu al-Wafa menuliskan ungkapan mistik Abu Yazid yang lain, seperti: "Betapa Sucinya Akum betapa besarnya Aku," "Aku keluar dari Abu Yazidku, seperti ular ke luar dari kulitnya, dan pandanganku pun terbuka, dan ternyata sang pecinta, Yang dicinta, dan dicinta, adalah satu. Sebab manusia itu dalam alam penyatuan adalah satu," "Maha Suci Aku! Aku inilah Tuhanku Yang Maha Luhur."

24 Abu al-Wafa al-Ghanimi al-Taftazani, Madkhal ila alTashawwuf al-Islam.

25 Abu al-Wafa al-Ghanimi al-Taftazani, Madkhal ila alTashawwuf al-Islam, h.115

26 Abu al-Wafa al-Ghanimi al-Taftazani, Madkhal ila alTashawwuf al-Islam, h.117.

27 Abu al-Wafa al-Ghanimi al-Taftazani, Madkhal ila alTashawwuf al-Islam, h.118.

28 Pembicaraan tentang al-Hallaj senantiasa memunculkan pro dan kontra sejak pertama kehadirannya sampai sekarang ini. Mereka yang menerima ajaran al-Hallaj-sebagian mereka ini- menganggap bhawa al-Hallaj sebagai Tuhan, sebagaimana anggapan umat Kristen terhadap Isa alMasih. Namun demikian, menurut penyelidikan penguasa Kerajaan pada masanya, al-Hallaj mempunyai hubungan dengan kaum Karamitah. Karamitah adalah sekelompok orang yang mepunyai paham seperti kaum komunis dewasa ini. Kelompok ini tumbuh berkembang pada abad 3-4 Hijriyah. Lihat selanjutnya, Hamka, Tasauf Perkembangan dan Pemurniannya, h. 114-115.

29 Hamka, Tasauf Perkembangan dan Pemurniannya, $\mathrm{h}$. 116.

30 Ibn Syuraih ini berkata, "Ilmuku tidak mendalam tentang dirinya, sebab itu saya tidak dapat berkata apa-apa."

31 Baik al-Ghazali maupun al-Rumi keduanya sepakat dan mendukung apa yang dialami al-Hallaj. Berikut perkataan al-Ghazali tentang Ana al-Haqq-nya alHallaj, "Perkataan yang demikian keluar dari mulutnya adalah dari karena sangat cintanya kepada Allah. Apabila sudah sekian mendalamnya, tidak dirasa lagi perpisahan di antara diri dengan yang dicintai."

32 Dibandingkan dengan para sufi pendukung al-Hallaj yang lainnya, Farid al-Din ini memberi gelar al-Hallaj dengan sebutan Syahid al-Haqq. Penyaksi Sang Kebenaran.

33 Abdulqadir al-Jailani-tokoh pendiri tarekat Qadarriyah ini-berkata, "Jika sekiranya saya hidup di zaman beliau (al-Hallaj), sudilah saya menjadi pengiringya."

34 Dukungan dari al-Damiri ini mengajak orang lain untuk bersikap berhati dalam memberi tuduhan orang Islam sebagai orang kafir. Bahkan memberi hukum pada orang karena pengalaman spiritual merupakan tindakan orang yang bodoh. Penulis Hayat al-Hayawan ini berkata, "Bukanlah perkara mudah menuduh seorang Islam keluar dari dalamnya. Kalau katakatanya masih dapat dita'wilkan (diartikan lain), lebih baik diartikan yang lain. Karena mengeluarkan seseorang dari lingkungan Islam, adalah perkara besar. Dan tergesa-gesa menjatuhkan hukum begitu, hanyalah perbuatan orang jahil.

35 Julian Baldick, Mystical Islam: an Introduction to Sufism, (London: New York University Press, 1992), h. 124. Sebutan teokrasi pada seseorang bahwa teokrasi adalah terbaik untuk menghindari. Istilah itu juga biasa digunakan umtuk mengartikan kekuasaan berdasarkan pada agama tertentu, yang secara harfiah berarti pemerintahan oleh Tuhan.

36 Julian Baldick, Mystical Islam: an Introduction to Sufism, h. 124.

37 Julian Baldick, Mystical Islam: an Introduction to Sufism, h. 124.

38 Julian Baldick, Mystical Islam: an Introduction to Sufism, 
h. 124 .

39 John A. Titaley, a Global Ethic With Abrahamic Religions: Is It Realistic?, Makalah diskusi pada Research Seminar Religion and Globalization: Friends or Foes? Religious Identity and Responsibility in a Globalized Word. Dilaksanakan oleh CRCS UGM pada tanggal 23-27 Mei 2006, di Yogyakarta.

40 Raden Sasrawijaya, Serat Sitidjenar, (Jogjakarta: Kulawarga Bratakesawa, 1958), h. 5.

41 Paul F. Knitter, the "One Earth": Common Ground For an Ecological Interreligious Dialogue, Makalah diskusi pada Research Seminar Religion and Globalization: Friends or Foes? Religious Identity and Resposibility in a Globalized Word. Dilaksanakan oleh CRCS UGM pada tanggal 23-27 Mei 2006, di Yogyakarta.

42 Istilah ini sering diterjemahkan dengan Unifikasionisme atau bertemunya dua hal. Hal ini berkaitam dengan pengalaman bersatu dengan Tuhan, setelah seorang sufi menjalani serangkaian petualangan rohani.

43 Istilah ini disepadankan dengan inkarnasi. Istilah ini melukiskan tentang Tuhan mendiami dalam diri Manusia. Proses ini terjadi bukan sebagai upaya manusia, melainkan sebagai kehendak Tuhan. Tuhan untuk memasuki dalam diri seseorang memilih sesuai dengan Kehendak dan Kuasa-Nya.

44 Paul F. Knitter, the "One Earth": Common Ground For an Ecological Interreligious Dialogue.

\section{DAFTAR PUSTAKA}

Abdullah, Hawwash. tt. Perkembangan Ilmu Tasawuf dan Tokoh-tokohnya di Nusantara. Surabaya: Al-Ikhlas.

Abdullah, M Amin. 1987. Sejarah dan Masyarakat: Landasan Historis Islam di Indonesia. Jakarta: Pustaka Firdaus.

Abdullah, M. Amin. 1999. Studi Agama: Normativitas atau Historisitas? Yogyakarta: Pustaka Pelajar.

Aceh, Abubakar. tt. Pengantar Sejarah Sufi dan Tasawuf. Surakarta: Ramadhoni.

Afifi, A.E. 1995. Filsafat Mistis Ibnu 'Arabi, Terj. Sjahrur Mawi dan Nandi Rahman. Jakarta: Gaya Media Pratama.

Amin, M Darori, Drs. MA. ed. 2000. Islam dan Kebudayaan Jawa. Yogyakarta: Gama Media.

Anderson, Benedict ROG. 1995. Mythology and Tolerance of Javanese. New York.

Ansari, Abdul Haq Muhammad. 1997. Merajut Tradisi Syari'ah dengan Sufisme: Mengkaji Gagasan Mujaddid Syeikh Ahmad Sirhindi. Jakarta: Srigunting.

Ardani, H. M. 1995. Sembah dan Budi dalam Serat-serat Piwulang Mangkunegara IV Surakarta. Makalah disampaikan dalam Pengukuhan Guru Besar IAIN Jakarta.

Armstrong, Amatullah, Sufi Terminologi (Al-Qamus al-Sufi): The Mystical Language of Islam, Kuala Lumpur: A.S. Noordeen.

Ashad, Kusumajaya. 2003. Pewaris Ajaran Syekh Siti Jenar: Membuka Pintu Makrifat, Yogyakarta: Kreasi Wacana.
Azra, Azyumardi. 1994. Jaringan Ulama Timur Tengah dan Kepulauam Nusantara abad XVII dan XVIII: Melacak Akar-akar Pembaharuan Pemikiran Islam di Indonesia, Bandung: Mizan.

Babad Cirebon. 1979. Alih aksara dan ringkasan oleh S.Z. Hadisutjipto, Jakarta: Departemen Pendidikan dan Kebudayaan Proyek Penerbitan Bacaan dan Sastra Indonesia dan Daerah.

Babad Jaka Tingkir: Babab Pajang. 1981. Alih aksara dan alih bahasa Moelyono Sasrtonaryatno, Jakarta: Departemen Pendidikan dan Kebudayaan Proyek Penerbitan Bacaan dan Sastra Indonesia dan Daerah.

Babad Majapahit dan Para Wali I. 1988. Proyek Penerbitan Buku Sastra Indonesia dan Daerah, Jakarta.

Bartakesawa. 1954. Falsafah Sitidjenar: Ngrewat Pangrembag Paham Wahdatul-Wujud (Pantheisme) Ing Tanah Djawi, Ingkang Menggok Dados Paham Ngaken Allah Tuwin Ngorakaken Wontenipun Ingkang Nitahaken (Atheisme). Surabaja: Jajasan Penerbitan,Djojobojo”.

Berg, CC. 1972. Penulisan Sejarah Jawa. Jakarta: Bharata.

Bertens, K. 1989. Sejarah Filsafat Yunani, Yogyakarta: Kanisius.

Bilal, Wasim, M. 1988. Mistik Dalam Suluk Pesisiran, Yogyakarta: Yayasan IImu Pengetahuan dan Kebudayaan "Panunggalan" Lembaga Javanologi.

Boekoe Siti Djenar Ingkang Toelen. 1931. Kediri: Tan Khoen Swie.

Bolland, B.J. 1985. Pergumulan Islam di Indonesia. Jakarta: Grafiti.

Bruinessen, Van, Martin. 1995. Kitab Kuning, Pesantren dan Tarekat: Tradisi-tradisi Islam di Indonesia, Bandung: Mizan.

Budiman, Amin. 1982. Walisongo Antara Legenda dan Fakta Sejarah, bagian I dan II, Semarang, Pn. Tanjung Sari.

Butterworth, E., Charles. ed. 1992. The Political Aspects Islamic Philosophy, Massachusetts, Cambridge: Harvard Univercity Press.

Chodjim, Achmad. 2002. Syekh Siti Jenar: Makna Kematian, Jakarta: Serambi.

Ciptoprawiro, Abdullah. 1986. Filsafat Jawa, Jakarta: Balai Pustaka.

D.A. Rinkes, De. 1986. Helligen van Java II: Sjeh Siti Djenar voor de Inquititie. Tijdschrift Bataviasch Genootschap deel III, 1911. Terjemahan, Orang-orang Suci Dari Jawa II: Syeh Siti Jenar di Muka Pengadilan, penj. M. Soenjata Kartadarmaja,Jakarta: Departemen Pendidikan dan Kebudayaan Direktorat Sejarah dan Nilai Tradisional, Proyek Inventarisasi dan Dokumentasi Sejarah Nasional.

Dahlan, Aziz, Abdul. 1992. "Tasawuf Samsuddin Sumatrani", Desertasi Doktoral Dalam Ilmu Agama Islam, Jakarta: Perpustakaan IAIN Jakarta.

Danusiri. 1996. Epistemologi Dalam Tasawuf Iqbal, Yogyakarta: Pustaka Pelajar.

Danuwijaya, HM. tth. Proses Timbulnya Ilmu Kebatinan dan 
Akibat-akibatnya, Semarang: Condro Kartiko.

Darban, A., Adaby. 1988. Kiyai dan Politik pada Zaman Kerajaan Islam Jawa, dalam Pesantren 5, No. 2.

Daudy, Ahmad. 1982. Falsafat Mistik Syeikh Hamzah Fansuri Dalam Sanggahan Syeikh Nuruddin Ar-Raniry, Al-Jami'ah, No. 27. Institut Agama Islam Negeri Sunan Kalijaga Yogyakarta., h. 32-33.

De Graaf, H.J. dan Th. Pigeud. 1985. Kerajaan-Kerajaan Islam Pertama di Jawa, Jakarta, Graffity Pers dan KITLV.

Fauzan, Aris. 2004. Ajaran Tasawuf Dalam Serat Siti Jenar (Telaah Kritis atas Serat Siti Jenar Karya Sunan Giri Kedhaton), Tesis: Universitas Islam Negeri Syarif Hidayatullah Jakarta.

2006. Siti Jenar: a Model of Indigenous Religion, a Religius Image Among Javanese People, Alamah: Jurnal Pembaharuan Pemikiran Islam, Vol. IV, JanuariDesember.

Fovler, James W. 1995. Teori Perkembangan Kepercayaan, Yogyakarta, Kanisius.

G. Moedjanto, MA. 1992. Drs., Tantangan Kemanusiaan Universal: Antologi Filsafat, budaya, Sejarah-Politik dan Sastra, Kenangan 70 tahun Dick Hartoko, Yogyakarta: Penerbit Kanisius.

Geertz, Clifford. 1989. Abangan, Santri, Priyayi dam Masyarakt Jawa, Jakarta: Pustaka Jaya.

Hadijaya, (ed.). 1999. Kelas Menengah Bukan Ratu Adil, Yogyakarta, PT Tiara Wacana.

Hadikusumo, H. Hilman. 1993. Antropologi Agama: Pendekatan Budaya Terhadap Aliran Kepercayaan, Agama Hindu, Budha, Kong Hu Cu di Indonesia, Bandung, Citra Aditya Bakti.

Hadiwijana, Harun, 1976. Konsep Tentang manusia dalam Kebatinan Jawa, Jakarta, Penerbit Sinar Harapan.

Hamka, Prof. Dr. 1994. Falsafah Hidup, Jakarta: Pustaka Panjimas.

1993. Tasauf Perkembangan dan Pemurniannya,

Jakarta: Pustaka Panjimas.

Hammersma, Harry, S.J. 1978. Teologi Metafisik, Yogyakarta: Kanisius.

Hardjawiraga, Marbangun. 1984. Manusia Jawa, Jakarta, Intidayu.

1979. Adat Istiadat Jawa, Bandung, Padma.

1971. Sari Falsafat India, Jakarta.

Hari Soewarno, Moh. tth. Syekh Siti Jenar, ttp: PT Antar Surya Jaya, tth.

Harjawijaya. 1926. Serat Suluk Wali Sana Jilit I - II, Kediri: Tan Khoen Swie.

Jamil, Abdul. Aspek Islam dalam Sastera Jawa, dalam M Darori Amin. 2000. Islam dan Kebudayaan Jawa, Yogyakarta: Gama Media.

Jong, S. De. 1976. Salah Satu Sikap Hidup Orang Jawa, Yogyakarta.

Journal Pemikiran Islam Paramadina. 1998. Vol. I Nomor 1, Juli - Desember. 1999. Vol. I Nomor 2..
Kamajaya. 1995. Karkono, Kebudayaan Jawa, Perpaduannya Dengan Islam, Yogyakarta, IKAPI DIY.

Kartapraja, Kamil. 1985. Aliran Kebatinan dan Kepercayaan Indonesia, Jakarta, Yayasan Masagung.

Kartasoedjonoredjo. 1950. Kitab Wali Sepuluh: Mengajar Ilmu Islam-Alam dan Kahanan Kepada Murid-muridnya, Kediri: Bukhandel Tan Khoen Swie.

Kodiran. 1954. Kebudayaan Jawa dalam Manusia dan Kebudayaan di Indonesia, Jakarta, Jambatan.

Koentjaraningrat. 1975. Manusia dan Kebudayaan di Indonesia, Jakarta, Djambatan.

Komaruddin Hidayat. 1996. Memahami Bahasa Agama: Sebuah Kajian Hermeneutik, Jakarta: Paramadina.

Lambard, Denys. 1996. Nusa Jawa: Silang Budaya, Bagian I: Batas-batas Pembaratan, Jakarta: Gramedia. 1996. Nusa Jawa: Silang Budaya, Bagian II: Jaringan Asia, Jakarta: Gramedia.

1996. Nusa Jawa: Silang Budaya, Bagian III: Warisan Kerajaan-kerajaan Konsentris, Jakarta: Gramedia.

Madjid, Nurcholish. 1985. Tasawuf Sebagai Inti Keberagaman, Pesantren, Vol. II, No. 3. 1984. Khazanah Intelektual Islam, Jakarta: Bulan Bintang.

Makalah Seminar 'Reaktualisasi Ajaran Walisanga Dalam Konteks Toleransi Antar Umat Beragama', yang diselenggarakan oleh Pusat Penelitian Budaya Jurusan Sejarah dan Peradaban Islam Fakultas Adab IAIN Yogyakarta dan Gatra-Majalah Berita Mingguan 12 November 2001

Mangun Wijaya. 1970. Syekh Siti Jenar, Surakarta: Museum Radyapustaka.

Massignon, Louis. 2000. al-Hallaj: Sang Sufi Syahid, Terj. Dewi Candraningrum Yogyakarta: Fajar Pustaka.

Muhtarom, Zaini. 1988. Santri dan Abangan di Jawa, Jakarta, IINIS, cet., ke-1.

Mulder, Neils. 1978. Kepribadian Jawa dan Pembangunan Nasional, Yogyakarta: Gadjah Mada Universty Press.

Muljana, Slamet. 1968. Runtuhnya Kerajaan Hindu Jawa dan Timbulnya Negara-negara Islam di Nusantara, Jakarta.

Mulkhan, Abdul Munir. 2001. Ajaran dan Jalan Kematian Syeikh Siti Jenar: Konflik Elite Dan Lahirnya Mas Karebet, Yogyakarta: Kreasi Wacana.

2002. Makrifat Burung Surga dan Ilmu Kasampurnan Syekh Siti Jenar: Memasuki Ajaran Kearifan Syekh Siti Jenar Dalam Serat Bayan Budiman, Yogyakarta: Kreasi Wacana.

2004. Makrifat Siti Jenar: Teologi Pinggiran Dalam Kehidupan Wong Cilik, Jakarta: Grafindo Khazanah Ilmu.

2000. Syekh Siti Jenar: Pergumulan Islam-Jawa,

Yogyakarta; Bentang Budaya. 1998. Bisnis kaum Sufi: Studi Tarekat dalam Masyarakat Industri, Yogyakarta: Pustaka Pelajar, cet., ke-1.

Mulyono, Sri. 1979. Simbolisme dan Mistikisme dalam 
Wayang, Jakarta.

Murata, Sachiko. 1998. The Tao of Islam: Kitab Rujukan Tentang Relasi Gender dalam Kosmologi dan Teologi Islam, Bandung: Mizan.

Nabilah Lubis. 2001. Naskah, Teks dan Metode Penelitian Filologi, Jakarta: Yayasan Media Alo Indonesia.

Nadim, Syaikh al-Jisr. 1998. Para Pencari Tuhan: Dialog AlQur'an, Filsafat, dan Sains dalam Bingkai Keimanan, Bandung, Pustaka Hidayah.

Nainar, S. Muhammad Husayn. 1956. Islam di India dan Hubungannya dengan Indonesia, Jakarta.

Nasr, Hossein, Seyyed. 1996. The Intellectual Tradition in Persia, Surrey: curzon Press.

Nasution, Harun. 1992. Falsafat dan Mistisisme dalam Islam, Jakarta: Bulan Bintang. 1986. Akal dan Wahyu Dalam Islam, Jakarta: Universitas Indonesia Press. 1992. Ensiklopedi Islam Indonesia, Jakarta:

Djambatan.

Falsafat Agama, Jakarta: Bulan Bintang.

1985. Islam Ditinjau dari Berbagai Aspeknya Jilid I

dan II, Jakarta: Universitas Indonesia Pres. 1998. Islam Rasional: Gagasan dan Pemikiran Prof.

Dr. Harun Nasution, Bandung: Mizan.

1987. Muhammad Abduh dan Teologi Rasional

Mu'tazilah, Jakarta: Universitas Indonesia Press.

Neco Kaptein et. al.1995. Delapan Tokoh Ilmuwan Belanda Bagi Pengkajian Islam Indonesia Seri INIS XXVII, Jakarta: INIS

Nicholson, A., Reynold. 1995. Aspek Rohaniah Peribadatan Islam di Dalam Mencari Keridhaan Allah, Terj. A. Nashir Budiman, Jakarta: PT. RajaGrafindo Persada.

Noer, Kautsar Azhari. 1995. Ibnu al-Arabi: Wahdat al-Wujûd dalam Perdebatan, Jakarta: Paramadina.

Palmer, Richard F. 1969. Hermeneutics: Interpretation Theory in Schleiermacher, Dilthey, Heidegger, and Gadamer, Northwestern: University Press.

Panji Natarata. 1958. Serat Sitidjenar: Njarijosaken lalampahan sarta iktikadipun wali Syekh Sitidjenar saha Kjai Kebokenanga ing Pengging, (Tembang) Jogkakarta: Kulawarga Bratakesawa.

Poedjawijatna, Prof. Ir. 1981. Manusia Dengan Alamnya: Filsafat Manusia, Jakarta: Bina Aksara.

Poejoesoebroto, R. 1978, Wayang Lambang Ajaran Islam, Jakarta: Pradnya Paramita.

Poerbatjaraka dan Tardjan Hadidjaja. 1952. Kepustakaan Jawa, Jakarta.

Poespowardojo, Soerjanto, ed. et. al.1982. Sekitar manusia; Bunga Rampai Tentang Filsafat Manusia, Jakarta: PT. Gramedia.

Prasetyo, Hendro. 1994. Mengislamkan Orang Jawa: Antropologi Baru Islam Indonesia, dalam Islamika, No. 3. Maret.

Purwadi. 2004. Gerakan Spiritual Syekh Siti Jenar, Yogyakarta: Media Abadi.
R. Woodward, Mark. 1999. Islam Jawa: Kesalehan Normatif versus Kebatinan, Yogyakarta: LkiS.

Raden Tanojo. 1954. Suluk Wali Sanga: Anggambarake mekare kawruh kebatinan kang pada ginilut para linuwih dek djaman pandjenengane Wali Sanga ing Nusa Djawa, nalika achier Karaton Madjapahit nganti tumeka awale Karaton Demak, Surakarta: R Tanojo.

Rahman, Fazlu. 1975. The Philosophy of Mulla Sadra (Sadr al-Din al-Shirazi), Albany: State University of New York press.

Ras, J. J. 1990., Tradisi Jawa Mengenai Masuknya Islam di Indonesia, Seri INIS.

Rasjidi, M. 1992. Islam dan Kebatinan, Jakarta: Bulan Bintang.

Robson. 1981. Java at The Crossroads: Aspect of Javanese Cultural History, ttp, Bijdragen.

Ronkel, Ph. S. Van. 1913. Suluk Syekh Lemahbang.

Saksono Widji. 1995. Mengislamkan Tanah Jawa: Telaah atas Metode Dakwah Walisongo, Bandung: Mizan. 1962. Islam Menurut Wejangan Wali Songo, Dalam Majalah al-Jami'ah, nomor 4-5, Tahun I, April-Mei.

Salam, Solihin. 1960. Sekitar Walisongo, Menara Kudus.

Schoun, Frithjof. 1987. Mencari Titik Temu Agama-agama, Jakarta: Pustaka Firdaus.

Serat Babad Tembayat 3, alih aksara dan bahasa Mulyono Sastranaryatmo, Jakarta: Departemen Pendidikan dan Kebudayaan.

Serat Seh Siti Djenar. 1936. Javaanche Uitgaven van Widya Poestaka, Indonessche Drukkerij, Weltevreden, 1917. Legaat Prof. Dr. C. Snouck Hurgrunje.

Serat Siti Jenar. 1922. Kediri, Solo: Tan Khoen Swie.

Sharif, M.M., ed. 1995. A History of Muslim Philosophy: With Short Accounts of Other Disciplines and The Modern Renaissance in Muslim Lands Vol I dan II, Delhi: Low Price Publication

Simuh, "Mistik Islam Kejawen dalam Wedhatama" (Paper disusun dan disajikan dalam rangka Diskusi Tetap Dosen-dosen IAIN Sunan Kalijaga), th., ke-6 Akademik $1983 / 1984$.

1988. Mistik Islam Kejawen Raden Ngabehi Ranggawarsita: Suatu Studi Terhadap Serat Wirid Hidayat Jati, Jakarta: Universitas Indonesia Press. 1999. Sufisme Jawa: Tranformasi Tasawuf Islam ke Mistik Jawa, Yogyakarta: Bentang Budaya.

Sjadzali, Munawir. 1995. Kontekstualisasi Ajaran Islam, Jakarta: IPHI dan Paramadina.

Sobary, Mohammad, Pengantar: Kewibawaan 'Subversif' Syekh Siti Jenar, dalam Abdul Munir Mulkhan. 2000. Syekh Siti Jenar: Pergumulan Islam-Jawa, Yogyakarta: Bentang Budaya.

Sofwan, Ridin, at. al 2000.. Islamisasi di Jawa: Walisongo, Penyebar Islam di Jawa, Menurut Penuturan Babad, Yogyakarta: Pustaka Pelajar. 1999. Menguak Seluk Beluk Aliran Kebatinan, Semarang, Aneka Ilmu. 
Steenbrink, Karel, A. 1988. Mencari Tuhan Dengan Kacamata Barat, Yogyakarta, IAIN Sunan Kalijaga Press.

Sujamto. 1997. Reorientasi dan Revitalisasi Pandangan Hidup Jawa, Semarang, Dahara Prize.

Sulami, Abd al-Rahman, Abu, al-. 1992. Futuwwah: Konsep Pendidikan Kekesatriaan di Kalangan Sufi, Bandung, alBayan.

Suluk Seh Siti Jenar, alih bahasa Sutarti, Jakarta: Departemen Pendidikan dan Kebudayaan Proyek Penerbitan Bacaan dan Sastra Indonesia dan Daerah, 1981.

Suluk Wali-wali Tanah Jawa, alih aksara dan penerjemah oleh Muhammad Khafid Kasri et.al., Jakarta: Universitas Indonesia, 1993.

Syahrastani, al-, Abdul Karim, Muhammad, Abu al-Fath, AlMilal wa al-Nihal, ttp: Dar al-Fikr, tth.

Syahrastani, al, Kitab Nihayah al-Aqdam Fi 'llmi al-Kalam, ttp:tth

Syaikh, Said, M., 1991. Kamus Filsafat Islam, Jakarta: PT RajaGrafindo Persada.

Taftazani al-, Abu al-Wafa' al-Ghanimi. 1997. Sufi Dari Zaman ke Zaman, Terj. Ahmad Rofi' 'Usman, Bandung: Penerbit Pustaka.

Thusi, al-, Nasr al-Din, Mushari' al-Mushari', ttp: tth.

Wahid, Abdurrahman. 1987. Islam dan Kebatinan: Sebuah Tinjauan Umum, Pustaka, No. I Th. Ii, Februari.

Wasit dkk. 1998. Penyebaran Islam di Jawa, IAIN Walisongo, Semarang.

Yulius Widiantoro, Pergeseran Ontologis Hermeneutik Berpedomankan Bahasa, dalam Driyarkara: Majalah Filsafat Sekolah Tinggi Filsafat Driyarkara, th. XX, No. 3 $1993 / 1994$

Ziai, Hossein. 1998. Suhrawardi Filsafat Illuminasi Penceramahan Ilmu Pengetahuan, Bandung: Zaman Wacana Mulia.

Zoetmulder, J.P. 1991. Manunggaling Kawula Gusti: Pantheisme dan Monisme Dalam Sastra Suluk Jawa Jakarta: Gramedia. 